\title{
The Effects of the Company's Approach to the Communities on Community Acceptance of Mining Company Activities
}

\author{
Noven Surya Pratama \\ Faculty of Economics and Business \\ University of Lampung \\ Bandar Lampung, Indonesia \\ novensuryap@gmail.com
}

\author{
Lindrianasari \\ Faculty of Economics and Business \\ University of Lampung \\ Bandar Lampung, Indonesia \\ lindrianasari@feb.unila.ac.id
}

\author{
Usep Syaipudin \\ Faculty of Economics and Business \\ University of Lampung \\ Bandar Lampung, Indonesia \\ usepsyaipudin@gmail.com
}

\begin{abstract}
Mining activities are sometimes related to mining companies in the middle of community settlements. Mining business permits owned by companies from the government are considered not strong enough to be able to gain community acceptance. Indirectly, the company needs a social permit from the community to ensure that its activities run smoothly. An intensive approach to the community is considered to increase community acceptance of mining activities. The company or the mine manager needs to build trust in the community first, because when the community already believes it will be easier to get acceptance from the community. This study aims to analyze the effect of Procedural Fairness, Intimacy of Contact, and Trust on Acceptance of Mining from people living around mining areas. This study involved 203 people living in the area around the mine in Lampung Province, Indonesia. The results of this study note that the Intimacy of Contact does not affect community Trust and Acceptance of Mining, while Procedural Fairness and Trust have a positive effect on community Acceptance of Mining.
\end{abstract}

Keywords:- Procedural Fairness; Trust; Acceptance of Mining; Intimacy of Contact.

\section{INTRODUCTION}

Environmental pollution is one of the impacts resulting from mining activities. One example of this is the gold mine in Babakan Loa Village, Kedondong Subdistrict, Pesawaran Regency, Lampung, which was temporarily closed by the government in 2019. (https://nasional.republika.co.id/berita/nasional/daerah/pok 5v2384/diduga-cemari-lingkungan-tambang-emas-

pesawaran-ditutup). Mining activities carried out by the company cause environmental pollution in residential areas around the mining site. One example of such environmental pollution is that water flowing into residential areas that are used for daily activities becomes polluted and harms health. The community considers the mining activities carried out by the company does not benefit those in the mining area, and causes more harm to them so that many people feel disadvantaged by the presence of the mine in the middle of their settlement.

However, it will be different when the company approaches the community before conducting mining activities. Community trust in the decision-makers of an organization can mediate the community in producing procedural Fairness in attitudes, and lead to increased acceptance of decisions from the community about mining activities Terwel et al. [14]. In other words, procedural fairness is about a person's involvement in a decision and whether their voice and input can be taken into consideration in the decision-making process to produce a mutually beneficial decision and be well received by Zhang \& Moffat [16]. Fair procedures will create the impression that individuals will do something and receive their share of the desired results from time to time. On the contrary, unfair procedures show that there are no such guarantees about the expected results to be received over time. This is because individuals or communities do not feel the results of mutually beneficial decisions.

Aside from procedural fairness, it is essential for companies also to be involved in daily community activities. Good relations established by mining companies are more effective in building trust in the community in Moffat \& Zhang [8] and Hall et al. [6]. Building trust with local communities is critical for mining companies to obtain and maintain support and acceptance of these operations. The quality of contact shapes this trust (but not quantity) and procedural Fairness through which mining companies deal with communities, as well as perceptions of how fairly mining benefits are distributed in the Moffat \& Zhang community [8] 


\section{LITERATUR REVIEW}

\section{A. Stakeholder Theory}

Stakeholder theory is a view that emphasizes the interrelated relationships between businesses and their customers, suppliers, employees, investors, communities, and others who have an interest in the organization. This theory argues that companies must create value for all stakeholders, not just shareholders. Social/community expectations of the company's business are changing, and shareholders are no longer the sole stakeholder in the organization's environment. People have this expectation because they consider the operational activities carried out by the company will have a direct and indirect negative impact on their lives such as the possibility of noise pollution caused by operating machines or environmental pollution caused by the presence of waste and environmental damage caused by might be caused by the company.

\section{B. Acceptance of Mining from Community}

The results of expectations and the actual reality on the ground will affect community acceptance. If the actual reality on the ground from mining activities is worse than expected, community acceptance of mining activities will decrease. Vice versa Moffat \& Zhang [8]. The following section aims to apply the social exchange theory framework to explain how people weigh the benefits associated with mining compared to the negative impact in determining the extent to which they receive mining development In accordance with social exchange theory, social exchange theory assumes that everyone will be rational in evaluating the impacts and benefits caused. Getting the maximum profit is not always possible so that trade-offs arise between the benefits obtained are smaller than the costs incurred, but these conditions can be accepted by the injured party when making an exchange.

\section{Building Trust in Community}

Trust is essential in gaining public acceptance. However, the form and rating of these trusts can be as different as the trust that occurs because of the relationship or interaction between the company and the community or the result of the quality of the relationship between the company and Moffat \& Zhang [8]. Indeed, communities are often very optimistic about working with mining companies in new developments because of the potential for mutual benefit. Therefore, it is essential for mining companies to establish positive contacts and can win the hearts and trust of the community. When the company has gained the trust of the community, it will be more comfortable and increasingly provide smooth mining activities in the community.

\section{Procedural Fairness}

Procedural fairness refers to the perceived fairness of the procedures used by the organization, and the supervisor makes Tyler's allocation decisions [15]. Terwel et al. [14] show that trust in an organization's decision-makers can mediate society in producing procedural justice in attitudes, leading to increased acceptance of decisions from the community. Procedural Fairness expected by workers is that they want to work with others, and they try to find a way to achieve the stability of the principle of cooperation without harming Zhang \& Moffat[16]. In other words, procedural justice is about a person's involvement in a decision and whether their voice and input can be taken into consideration in the decision-making process, so can produce mutually beneficial decisions both parties and can be well received in Zhang \& Moffat [16]

\section{E. Intimacy of Contact}

The intimacy of contact between company personnel and community members can have a significant influence on the quality of company-community interaction. Extensive research shows that positive contact or interaction between groups can improve intergroup relations and increase trust between groups Hewstone et al. [7]; Pettigrew $\&$ Tropp [10]. This has proven equally right when tested in mining contexts. What makes the difference in trust and acceptance is the amount of contact between the company and the community. For example, in a longitudinal survey of community attitudes towards mining, Moffat \& Zhang [8] found that the quality of contact between mining company personnel and community members was a significant predictor of trust in the company and acceptance of its operations Intimacy of Contact by the company can be carried out by regular visits conducted by the company by listening to the aspirations and desires of the community towards the company.

\section{HYPOTHESIS AND EQUATION}

\section{A. Procedural Fairness dan Trust}

Moffat \& Zhang [8] and Zhang et al. [17] found that when community aspirations were more considered, trust in mining companies would run well to increase revenue from mining activities. Mining companies that can create and provide opportunities for communities to participate and consult can increase the acceptance of the Owen and Kemp mining activities [9]. For example, in a study of communities affected by mining in Australia, Cheney et al. (2001) found that local communities often felt marginalized in what was considered a predetermined development trajectory that was jointly defined by the government and mining companies. Things like this can affect people's trust, which in turn will make people's trust imperfect.

\section{Ha1: Procedural Fairness has a positive and significant influence on community trust}

\section{B. Procedural Fairness dan Acceptance of Mining}

The presence of reasonable process requirements creates a disincentive for managers to discipline or stop people performing poorly. Franklin \& Pagan [5] suggested that organizations develop informal mechanisms to discipline or lay off employees who perform poorly, thus avoiding rules made to protect employees and treat them fairly. People are willing to accept unfavorable results (e.g., lower salary increases, promotions rejected, or training opportunities) if the allocation is based on fair and fair procedures. These arguments make procedural justice important for public service organizations where allocations are made in Rubin's limited resource world [12]. Besley [1] states that the research shows that the acceptance of 
decisions is strongly influenced by whether people have been allowed to participate in the decision-making process carried out by the company. De Cremer et al. [4] said that Procedural Fairness was also found to be related to participation in a process that could enhance social cooperation. Procedural Fairness was also found to have a direct correlation between individuals' perceptions of procedural Fairness and an increase in their acceptance of the results of individual decisions or activities even in cases where they might not directly benefit from the results of decisions made, or even where they also received very unfavorable results.

Ha2: Procedural Fairness has a positive and significant influence on society's Acceptance of Mining

\section{The intimacy of Contact and Trust}

Moffat \& Zhang [8] and Hall et al. [6] found that good relations established by mining companies were more effective in building trust in the community. Conde and Billon [2] further said that if a company can create an ethical and sustainable relationship, it can increase public trust.

Ha3: Intimacy of Contact has a positive and significant influence on community Trust.

\section{The intimacy of Contact dan Acceptance of Mining}

There is real value in understanding how the attitude of the general public towards mining can affect local conditions for acceptance of mining operations, and how local problems affect decision making by companies and governments on a national scale. It is also essential to be able to bring citizens' voices into decision making regarding the development of Moffat \& Zhang's mineral resources [8]. The failure of explicit community acceptance can be caused when the community is not involved in the consultation process around the development of new or existing resources, where the potential for unsuitable expectations among stakeholders in this operation is high in Kapelus, 2002; Prno and Slocombe [11]; Owen and Kemp [9]. The absence of a consistent approach taken by the company can also make people not know the company well, which in turn will affect the community's acceptance of the company.

Ha4: Intimacy of Contact has a positive and significant influence on community Acceptance of Mining.

\section{E. Trust dan Acceptance of Mining.}

Moffat \& Zhang [8] and Zhang et al. [17] concluded that when trust is built between the community and the mining company, mining activities are more acceptable to the community. As a case study at PT. Aneka Tambang Tbk realizes that the company's success cannot be achieved without public trust. When public trust increases, of course, it gives value to the company itself. The results of expectations and the actual reality on the ground will affect community acceptance. If the actual reality on the ground from mining activities is worse than what was expected, then community acceptance of mining activities will decrease, and vice versa Moffat \& Zhang [8].
Has: Trust has a positive and significant influence on Acceptance of Mining

\section{EQUATION AND RESEARCH MODEL}

\section{A. Equation}

\author{
Acceptance of Mining $=\alpha+\beta 1$ Trust $+\mathrm{e}$ \\ Trust $=\alpha+\beta 1$ Procedural Fairness $+\beta 2$ Intimacy of Contact \\ $+e$
}

Acceptance of Mining $=\alpha+\beta 1$ Procedural Fairness $+\beta 2$ Intimacy of Contact $+\beta 3$ Trust $+\mathrm{e}$

\section{B. Research Model}

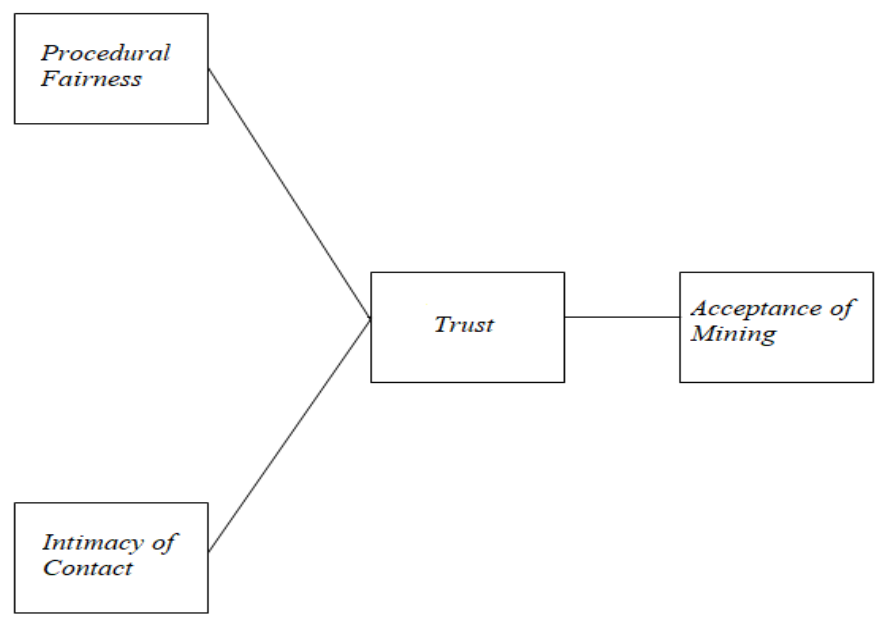

Fig 1

\section{RESEARCH METHOD}

\section{A. Data Types and Sources}

This type of research is a field survey. Survey research method or simply called survey method is research whose primary source of data and information is obtained from respondents as research samples using questionnaires or questionnaires as data collection instruments. The data source of this research came from speakers who conducted direct interviews to ensure that the data's validity directly came from the people living around the mining area.

\section{B. Study Population and Sample}

The population in this study are all people who live around the location of the mining area within a radius of \pm 1 $\mathrm{km}$ from the mining location. The sample used in this study was 203 communities living around the mining area.

\section{Research Variables and Measurements}

\section{Independent Variable}

The dependent variable of this study is the Acceptance of Mining. Measurement of this variable refers to research conducted by Zhang \& Moffat [16] entitled "A balancing act: The role of benefits, impacts, and confidence in governance in predicting acceptance of mining in Australia." The dependent variable in this study was measured using questionnaires number 1 to 5 in the 
appendix. Questionnaires are given to respondents in the form of statements using the Likert scale 1-7, where the scale of 1 (strongly disagree) to 7 (strongly agree).

\section{Independent Variable}

\section{a) Procedural Fairness}

Procedural Fairness was measured by three items adapted from the journal Moffat \& Zhang [8], entitled "The Paths to Social License to Operate: An Integrative Model Explaining Community Acceptance of Mining." This variable measures the community's opinion of the extent of influence and involvement in company decision making. Measurements made to measure this variable using questionnaires number 30 to 33 in the attachment to the question. Questionnaires are given to respondents in the form of statements using the Likert scale 1-7, where the scale of 1 (strongly disagree) to 7 (strongly agree).

\section{b) Intimacy of Contact}

Building positive contacts is an essential thing for companies to do because it will increase the trust of the community. The positive contact that exists between mining companies and community members living around the mine must create goodwill and trust, which in turn will increase the likelihood that mining developments will be accepted by the community, which in the end that social licenses will be granted by the Moffat \& Zhang communities [8]. This variable is used to measure how far the mining company knows the community around the mine and how often the mining company has two-way communication with the community. Measurements made to measure this variable using questionnaires number 27 to 29 in the attachment to the question. Questionnaires are given to respondents in the form of statements using the Likert scale 1-7, where the scale of 1 (strongly disagree) to 7 (strongly agree).

\section{c) Trust}

Cook [3] said that trust is related to public trust in companies. Trust is defined as the community having confidence that the company's behavior will be in line with the expectations of the community around the mine. Important in obtaining a social license from the community, community trust represents the extent to which the general public has confidence in mining companies. Communities may be expected to respond positively to mining companies where the company will not take profits that cause harm to the community itself, show integrity and competence in how they manage the risks represented by their operations, work with them and meet community expectations of corporate behavior Moffat \& Zhang [8]. This variable measures the community's trust in the company and the extent of their influence and involvement in company decision making. Measurements made to measure this variable using questionnaires number 34 to 37 in the attachment to the question. Questionnaires are given to respondents in the form of statements using the Likert scale 1-7, where the scale of 1 (strongly disagree) to 7 (strongly agree).

\section{RESULT AND DISCUSSION}

\section{A. Descriptive Analysis}

The profile of respondents participating in this study is shown in the following table:

\begin{tabular}{|c|c|c|}
\hline Sex & Frequent & Percentage \\
\hline Man & 113 & $55,67 \%$ \\
\hline Woman & 90 & $44,33 \%$ \\
\hline Total & $\mathbf{2 0 3}$ & $\mathbf{1 0 0 \%}$ \\
\hline
\end{tabular}

Tabel 1:- Details of Participants by Gender

From the table, we can see a description of the sex and age of the respondent. When viewed from the gender of male respondents more than women, namely 113 men (55.67\%) compared to women as many as 90 people $(44.33 \%)$. The average age of respondents is in the age range $26-45$ years as many as 86 people $(42.36 \%)$ and the age range $46-65$ years as many as 90 people $(44.33 \%)$. The average citizen who lives around the mine has completed high school education and has lived near the mining area for more than five years.

\begin{tabular}{|c|c|c|}
\hline Dependent Variable & $\boldsymbol{R}$ Square & $\boldsymbol{R}$ Square Adjusted \\
\hline Acceptance of Mining & 0,953 & 0,953 \\
\hline Trust & 0,040 & 0,030 \\
\hline
\end{tabular}

R-Squares values in table II mentioned that $95.3 \%$ of the independent variables in this study could explain the Acceptance of Mining variable. In comparison, only $4 \%$ of the independent variables can explain the Trust variable; the remaining $96 \%$ is explained by other variables outside this study.

\section{B. Data Analysis}

Bootstrapping test results in this study from the PLS analysis are as follows:

\begin{tabular}{|l|c|c|c|}
\hline \multicolumn{1}{|c|}{ Research Variable } & Original Sample & P-Values & Research Result \\
\hline Procedural Fairness $->$ Trust & 0,033 & 0,044 & Accepted \\
\hline Procedural Fairness $->$ Acceptance of Mining & 0,021 & 0,782 & Accepted \\
\hline Intimacy of Contact $->$ Trust & 0,037 & 0,123 & Rejected \\
\hline The intimacy of contact -> Acceptance of Mining & 0,198 & 0,038 & Accepted \\
\hline Trust -> Acceptance of Mining & 0,967 & 0,000 & \\
\hline
\end{tabular}

Tabel 3:- Data Processing Results 
The influence of Procedural Fairness on Trust shows a path coefficient of 0.033 with a p-value of 0.044 . The value of the p-value is less than 0.05, and this means that hypothesis 1 is accepted. Then, the influence of Procedural Fairness on Acceptance of Mining was also accepted with a coefficient value of 0.021 and a p-value of 0.782 . This study's results are consistent with those carried out by genetic Siegrist et al. [13]. Which has found a direct correlation between individual perceptions of procedural Fairness and an increase in their acceptance of the outcome of a particular decision or activity in an event where they may not directly benefit from the outcome of the decision. This research is also following research conducted by Moffat and Zhang [16], which states that it is essential for companies to involve companies in decision making and ultimately will increase trust and generate acceptance from the public.

The effect of Intimacy of Contact on Trust shows a coefficient value of 0.037 with a p-value of 0.123 , and Intimacy of Contact of Acceptance of Mining indicates 0.198 with a p-value of 0.038 . This means that the two Intimacy of Contact hypotheses were rejected both of Trust and Acceptance of Mining. The community does not mind if the company does not make regular contact with them; this does not affect the community's acceptance of mining activities. This research follows the results of research conducted by Moffat \& Zhang [8], which states that contact quantity does not have a significant effect on trust, which will affect community acceptance.

The influence of Trust on Acceptance of Mining shows a path coefficient of 0.967 with a p-value of 0,000 . This means that hypothesis five is accepted. This is consistent with research conducted by Moffat \& Zhang [8]. Community trust is the primary key in community acceptance of mining activities to be carried out by the company. The community will feel disturbed if there are disturbances that occur around their residence. This is the following stakeholder theory because it is proven that the community has an interest in their place of residence, so they do not want to feel aggrieved. Social permission from the community is no less critical for mining management companies to get maximum results in carrying out operational activities.

\section{CONCLUSION}

The primary key to get Acceptance of Mining from the people who live around the mining area is to trust the community. This is very influential on community acceptance because people feel valued and involved in the company's business decisions. The intimacy of contact from the mine management representative did not significantly influence the community living around the mine. Procedural Fairness has a significant effect because with transparent business processes and with increasing community participation in making decisions about how mining operations will be developed, designing and implementing fair processes have become an essential part of creating equity. Participation, creating meaningful dialogue among stakeholders. Trust has a significant and positive influence on the Acceptance of Mining of the people who live around the mining area because when the community believes in the mine manager that they get more benefits than the loss they feel, then they will be able to accept the presence of mining activities in the middle of the site they live.

\section{REFERENCES}

[1] Besley, J. C. (2010). Public engagement and the impact of fairness perceptions on decision favorability and acceptance. Science Communication, 32(2), 256280. https://doi.org/10.1177/1075547009358624

[2] Conde, M., \& Le Billon, P. (2017). Why do some communities resist mining projects while others do not? Extractive Industries and Society, 4(3), 681-697. https://doi.org/10.1016/j.exis.2017.04.009

[3] Cook, K. S. (2015). Exchange: Social. In International Encyclopedia of the Social \& Behavioral Sciences: Second Edition (Second Edi, Vol. 8). Elsevier. https://doi.org/10.1016/B978-0-08-097086-8.32056-6

[4] De Cremer, D., Tyler, T. R., \& den Ouden, N. (2005). Managing cooperation via procedural Fairness: The mediating influence of self-other merging. Journal of Economic Psychology, 26(3 SPEC. ISS.), 393-406. https://doi.org/10.1016/j.joep.2004.12.004

[5] Franklin, A. L., \& Pagan, J. F. (2006). Organization Culture as an Explanation for Employee Discipline Practices. Review of Public Personnel Administration, 26(1), 52-73. https://doi.org/10.1177/0734371X05277335

[6] Hall, N., Lacey, J., Carr-Cornish, S., \& Dowd, A. M. (2015). Social license to operate: Understanding how a concept has been translated into practice in energy industries. Journal of Cleaner Production, 86, 301310. https://doi.org/10.1016/j.jclepro.2014.08.020

[7] Hewstone, M., Lolliot, S., Swart, H., Myers, E., Voci, A., Ramiah, A. Al, \& Cairns, E. (2014). Intergroup contact and intergroup conflict. Peace and Conflict, 20(1), 39-53. https://doi.org/10.1037/a0035582

[8] Moffat, K., \& Zhang, A. (2014). The paths to social license to operate: An integrative model explaining community acceptance of mining. Resources Policy, 39(1),

61-70. https://doi.org/10.1016/j.resourpol.2013.11.003

[9] Owen, J. R., \& Kemp, D. (2013). Social license and mining: A critical perspective. Resources Policy, $38(1)$, 29-35. https://doi.org/10.1016/j.resourpol.2012.06.016

[10] Pettigrew, T. F., \& Tropp, L. R. (2006). A metaanalytic test of intergroup contact theory. Journal of Personality and Social Psychology, 90(5), 751-783. https://doi.org/10.1037/0022-3514.90.5.751

[11] Prno, J., \& Scott Slocombe, D. (2012). Exploring the origins of "social license to operate" in the mining sector: Perspectives from governance and sustainability theories. Resources Policy, 37(3), 346357. https://doi.org/10.1016/j.resourpol.2012.04.002 
[12] Rubin, E. V. (2009). The role of procedural justice in public personnel management: Empirical results from the department of defense. Journal of Public Administration Research and Theory, 19(1), 125-143. https://doi.org/10.1093/jopart/mum035

[13] Siegrist, M., Connor, M., \& Keller, C. (2012). Trust, Confidence, Procedural Fairness, Outcome Fairness, Moral Conviction, and the Acceptance of GM Field Experiments. Risk Analysis, 32(8), 1394-1403. https://doi.org/10.1111/j.1539-6924.2011.01739.x

[14] Terwel, B. W., Harinck, F., Ellemers, N., \& Daamen, D. D. L. (2010). Voice in Political Decision-Making: The Effect of Group Voice on Perceived Trustworthiness of Decision Makers and Subsequent Acceptance of Decisions. Journal of Experimental Psychology: Applied, 16(2), 173-186. https://doi.org/10.1037/a0019977

[15] Tyler, T. R. (2000). Social Justice: Outcome and Procedure. International Journal of Psychology, 35(2), 117-125. https://doi.org/10.1080/002075900399411

[16] Zhang, A., \& Moffat, K. (2015). A balancing act: The role of benefits, impacts, and confidence in governance in predicting acceptance of mining in Australia. Resources Policy, 44, 25-34. https://doi.org/10.1016/j.resourpol.2015.01.001

[17] Zhang, A., Moffat, K., Lacey, J., Wang, J., González, R., Uribe, K., Cui, L., \& Dai, Y. (2015). Understanding the social license to operate of mining at the national scale: A comparative study of Australia, China, and Chile. Journal of Cleaner Production, 108, 1063-1072.

https://doi.org/10.1016/j.jclepro.2015.07.097 